\title{
The detection of fibrinogen/fibrin degradation products by means of a new antibody-coated latex particle
}

\author{
M. BERNADETTE GARVEY AND JOAN M. BLACK
}

From St Michael's Hospital and the Department of Medicine, University of Toronto, Canada

SYNOPSIS A rapid slide test for the detection of degradation products of fibrinogen/fibrin (FDP) using a new antibody-coated latex particle is described. The latex particle has been specifically $\infty_{\infty}$ coated with antibody to fragments $\mathrm{D}$ and $\mathrm{E}$. The latex agglutination test (Thrombo-Wellcotest)

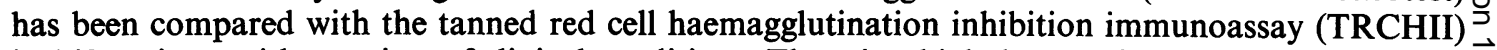
in 143 patients with a variety of clinical conditions. There is a high degree of agreement between the methods with a coefficient of correlation of 0.83 . The method provides a rapid, simple screening test迄 for fibrin degradation products.

Several methods are presently available for measuring products of fibrinogen/fibrin degradation by plasmin. The demonstration of these products constitutes a valuable means of detecting consumption coagulopathy or primary fibrinolysis. The most widely used techniques available are the TRCHII (Merskey, Kleiner, and Johnson, 1966), immunodiffusion, and immunoelectrophoresis (Nussenzweig, Seligmann, and Grabar, 1961; Niléhn and Nilsson, 1964; Ferreira, Murat, and Ferri, 1964; Fisher, Fletcher, Alkjaersig, and Sherry, 1967), precipitin tests (Hirsh, Fletcher, and Sherry, 1965; Stiehm and Trygstad, 1969), the staphylococcal clumping test (Lipínski, Hawiger, and Jeljaszewicz, 1967; Hawiger, Niewiarowski, Gurewich, and Allington, 1967; Thomas, 1970), and agglutination of latex particles (FI) (Thomas, Niewiarowski, Myers, Bloch, and Colman, 1970; Marder, Matchett, and Sherry, 1971). A comparative study of the commonly used methods has recently been reported by Thomas et al (1970) who found a good correlation between the results obtained using the staphylococcal clumping test, the TRCHII, and the latex agglutination test. Each of these methods has limitations for widespread use in clinical situations requiring rapid results. Immunodiffusion requires a 48-hour incubation period and appears to be insensitive to values below $40 \mu \mathrm{g} / \mathrm{ml}$. The staphylococcal clumping test and the TRCHII are time consuming and technically demanding. Agglutination of antibodycoated latex particles provides a simple rapid screening method for the detection of fibrinogen/ Received for publication 4 May 1972. fibrin degradation products. However, the presently available FI test has been reported to give a high $\square$ degree of negative results (Castelan, Hirsh, and Martin, 1968; Thomas et al, 1970; Cohen, 1970). Thomas et al (1970) have suggested that this may be due to the fact that the FI test is not sensitive to fragment $E$.

A new antibody-coated latex particle ThromboWellcotest, coated specifically with anti-D and anti$\mathrm{E}$, is now available. We have compared the use of Thrombo-Wellcotest with the TRCHII.

\section{Materials and Methods}

The latex particles were supplied by the Wellcome Research Laboratory and were prepared in the following manner as described by Pitcher (1971).

Purified human fibrinogen was digested by the enzyme plasmin to give stage 3 degradation productso -fragments $D$ and $E$. These were separated from contaminants by agarose gel electrophoresis, mixed $O$ in equal quantities, emulsified in adjuvant, and $\widetilde{O}$ injected into rabbits. The resulting immune serum N was absorbed with a solid polymer of normal human serum (Avrameas and Ternynck, 1969) containing negligible amounts of FDP to remove any cross reactions to other serum proteins. Specific globulins@ were extracted and used to sensitize latex particles 0 to give a rapid slide test sensitive to $2 \mu \mathrm{g} / \mathrm{ml}$ of fibrinogen.

One hundred and forty-three sera from patients $\frac{\rho}{8}$ with a variety of pathological conditions were evaluated. Five millilitres of venous blood was 
collected by means of a plastic disposable syringe and a 20 gauge needle. The blood was transferred to a glass test tube containing $0.1 \mathrm{ml}$ of Trasylol ${ }^{1}$ $(5000 \mathrm{u} / \mathrm{ml})$ and incubated in a water bath at $37^{\circ} \mathrm{C}$ for two hours. After incubation the specimen was centrifuged at $3000 \mathrm{rpm}$ for 10 minutes and the serum removed. The whole volume of serum was mixed with one-tenth of its volume of a solution of thrombin ${ }^{2}$ containing $100 \mathrm{u} / \mathrm{ml}$. The serum-thrombin mixture was incubated for 30 to 60 minutes, again centrifuged and stored at $-70^{\circ} \mathrm{C}$ in $1 \mathrm{ml}$ aliquots.

The serum was thawed at $37^{\circ} \mathrm{C}$ and dilutions of 1 in 4,1 in 16 , and 1 in 64 were made in glycinesaline buffer $^{3} p H \mathbf{8} \cdot 2$. The latex agglutination tests were performed on opaque glass plates similar to those used in latex particle pregnancy tests. One drop of each serum dilution was added to one drop of latex particle suspension ${ }^{4}$ and mixed by means of an applicator stick. Standardized drops were delivered from microhaematocrit capillary tubes. The plate was rotated gently for two minutes and the reaction was timed with a stop watch.

Positive reactions showed macroscopically visible agglutination in less than two minutes. High titre sera were found to give positive results more rapidly than those with low titres.

A $10 \mu \mathrm{g} / \mathrm{ml}$ fibrinogen standard provided by the

${ }^{1}$ F.B.A. Pharmaceutical Ltd, Pointe Claire, PQ.

${ }^{2}$ Parke Davis \& Co. Ltd, Brockville, Ontario.

'Hoechst Pharmaceutical Co., Montreal, PQ.

'Wellcome Research Laboratories, Beckenham, Kent, UK.
Wellcome Research Laboratory was used as a control. The latex agglutination test gave a positive reaction at a fibrinogen concentration of $2 \cdot 0 \mu \mathrm{g} / \mathrm{ml}$.

In determining the relationship between the rapid slide test and the FDP titre, quantitative estimations were performed by means of the Wellcome FDP $\mathbf{k i t}^{4}$, which employs the TRCHII technique of Merskey et al (1966). The normal range in our laboratory is 0 to $10 \mu \mathrm{g} / \mathrm{ml}$.

\section{Results}

The results are tabulated in the Figure. There is very close agreement between the results obtained using the latex particle agglutination test and the TRCHII. Using the criterion outlined in the Table there is absolute agreement between the two methods in 100 of 143 cases. The coefficient of correlation is 0.833 . In 10

\begin{tabular}{llll}
\hline Serum Dilution & & & $\begin{array}{l}\text { FDP Range } \\
(\mu \mathrm{g} / \mathrm{ml})\end{array}$ \\
\hline $1 / 4$ & $1 / 16$ & $1 / 64$ & \\
\hline $\mathrm{Neg}$ & $\mathrm{Neg}$ & $\mathrm{Neg}$ & $0-8$ \\
Pos & Neg & Neg & $8-31$ \\
Pos & Pos & Neg & $32-127$ \\
Pos & Pos & Pos & $>128$ \\
\hline
\end{tabular}

Table Results with Thrombo-Wellcotest ${ }^{1}$

${ }^{1}$ The sensitivity of Thrombo-Wellcotest is $2.0 \mu \mathrm{g} / \mathrm{ml}$. The values tabulated above represent the corresponding range of FDP, found in each dilution.

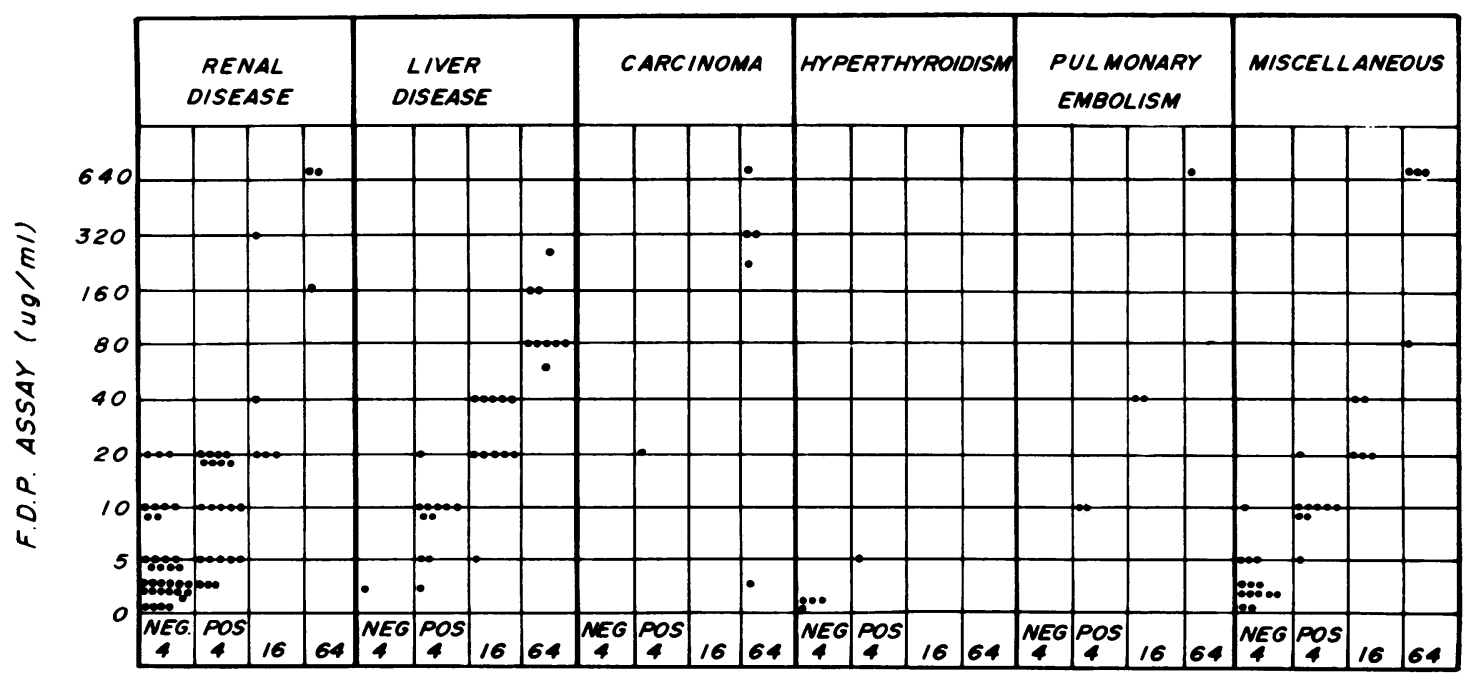

F.D.P. LATEX SCREENING TEST (TITRE)

Fig. Relationship between the FDP assay and the FDP screening test in various pathological conditions. 
cases the latex agglutination test gave results slightly lower than those demonstrated by the TRCHII. In 31 cases the results obtained by the latex agglutination test were slightly higher than those detected by the TRCHII, indicating that in these cases the latex agglutination test was slightly more sensitive. Of these 41 cases, 35 , or $85 \%$, were at levels not greater than $20 \mu \mathrm{g} / \mathrm{ml}$, and therefore not considered to be in a clinically significant range. In only two of the 143 cases was there a discrepancy of more than 1 dilution. In one case, high levels of cryofibrinogen appeared to obscure the results in the TRCHII. The second case represented a patient with an acute rejection of a renal transplantation. The TRCHII gave a level significantly higher than the latex agglutination test. We have no explanation for this discrepancy.

\section{Discussion}

The use of the latex particles coated with antibody to the late products of fibrin degradation, fragments $D$ and $\mathrm{E}$, constitutes a simple and rapid screening technique for the detection of fibrinogen/fibrin degradation products. The correlation between Thrombo-Wellcotest and the established TRCHII is extremely good. From this study it would appear that the latex particle method is useful in identifying very low levels of degradation products and can be used with a high degree of accuracy as a screening procedure.

The Thrombo-Wellcotest was supplied by WarnerChilcott Laboratories, Toronto. Their support is gratefully acknowledged.

\section{References}

Allington, M. J. (1967). Fibrinogen and fibrin degradation products and the clumping of staphylococci by serum. Brit. J. Haemat., 13, 550-567.

Avrameas, S., and Ternynck, T. (1969). The cross-linking of proteins with glutaraldehyde and its use for the preparation of immunoadsorbents. Immunochemistry, 6, 53-66.

Castelan, D. J., Hirsh, J., and Martin, M. (1968). Latex-bound antifibrinogen test for plasma fibrinogen assay. J. clin. Path., 21, 638-642.

Cohen, R. J. (1970). Measurement of fibrinogen degradation products. New. Engl. J. Med., 283, 1465.

Ferreira, H. C., Murat, L. G., and Ferri, R. G. (1964). Rapid test for fibrinolysis in vivo. Transfusion, 4, 21-25.

Fisher, S., Fletcher, A. P., Alkjaersig, N., and Sherry, S. (1967). Immunoelectrophoretic characterization of plasma fibrinogen derivatives in patients with pathological plasma proteolysis. J. Lab. clin. Med., 70, 903-922.

Hawiger, J., Niewiarowski, S., Gurewich, V., and Thomas, D. P. (1970). Measurement of fibrinogen and fibrin degradation $\frac{?}{0}$ products in serum by staphylococcal clumping test. J. Lab. clin. Med., 75, 93-108.

Hirsh, J., Fletcher, A. P., and Sherry, S. (1965). Effects of fibrin and fibrinogen proteolysis products on clot physical properties. Amer. J. Physiol., 209, 415-424.

Lipínski, B., Hawiger, J., and Jeljaszewicz, J. (1967). Staphylococcal clumping with soluble fibrin monomer complexes. J. exp. Med., 윽 126, 979-988.

Marder, V. J., Matchett, M. O., and Sherry, S. (1971). Detection of serum fibrinogen and fibrin degradation products. Amer. J. Med., 51, 71-82.

Merskey, C., Kleiner, G. J., and Johnson, A. J. (1966). Quantitative estimation of split products of fibrinogen in human serum; relation to diagnosis and treatment. Blood, 28, 1-18.

Niléhn, J. E., and Nilsson, I. M. (1964). Demonstration of fibrinolytic split products in human serum by an immunological method in N spontaneous and induced fibrinolytic states. Scand. J. Haemat., 1, 313-330.

Nussenzweig, V., Seligmann, M., and Grabar, P. (1961). Les produits de dégradation fibrinogène humain par la plasmine. II. Étude immunologique: mise en évidence d'anticorps anti-fibrinogène natif possedant des spécificités différentes. Ann. Inst. Pasteur., 100, 490-508.

Pitcher, P. M. (1971). Preparation of a rapid slide test for the detection of fibrinogen degradation products (F.D.P.) in serum and a preliminary report on its use as a clinical screening test. (Abstr.) In Proceedings of the International Society on Thrombosis and Haemostasis, Oslo, p. 282.

Stiehm, E. R., and Trygstad, C. W. (1969). Split products of fibrin in human renal disease. Amer. J. Med., 46, 774-786.

Thomas, D. P., Niewiarowski, S., Myers, A. R., Bloch, K. J., and Colman, R. W. (1970). A comparative study of four methods of detecting fibrinogen degradation products in patients with various diseases. New Engl. J. Med., 283, 663-668. 